\title{
Safety and tolerance of a new extensively hydrolyzed rice protein-based formula in the management of infants with cow's milk protein allergy
}

\author{
Yvan Vandenplas • Elisabeth De Greef • Bruno Hauser • \\ Paradice Study Group
}

Received: 26 December 2013 /Revised: 3 March 2014 / Accepted: 24 March 2014 / Published online: 12 April 2014

(C) The Author(s) 2014. This article is published with open access at Springerlink.com

\begin{abstract}
Guidelines recommend the use of extensively hydrolyzed cow's milk protein-based formulas (eHF) in the treatment of infants with cow's milk protein allergy (CMPA). Extensively hydrolyzed rice protein infant formula (eRHF) has recently become available and could offer a valid alternative. A prospective trial was performed to evaluate the hypo-allergenicity and safety of a new eRHF in infants with a confirmed CMPA. Patients were fed the study formula for 6 months. Clinical tolerance of the eRHF was evaluated with a symptom-based score (SBS) and growth (weight and length) was monitored. Forty infants (mean age, 3.4 months; range, 1-6 months) with CMPA confirmed by a food challenge were enrolled. All infants tolerated the eRHF and the SBS significantly decreased as of the first month of intervention. Moreover, the eRHF allowed a catch-up to normal weight gain as of the first month as well as a normalization of the weight-for-age, weight-for length, and BMI $z$-scores within the 6-month study period. Conclusion: In accordance with current guidelines, this eRHF was tolerated by more than $90 \%$ of children with proven CMPA with a $95 \%$ confidence
\end{abstract}

Communicated by David Nadal

Paradice Study Group: C. Halut, MN. Robberecht, N. Balduck, A. l'Homme, MP. Mohring, T. Carvelli, E. Defontaine, JF. Questiau, J. Christens, F. Henckens, R. Lemmens, L. Vercammen

Y. Vandenplas $(\bowtie) \cdot$ E. De Greef $\cdot$ B. Hauser

Department of Pediatrics, UZ Brussel, Vrije Universiteit Brussel,

Brussels, Belgium

e-mail: yvan.vandenplas@uzbrussel.be

E. De Greef

e-mail: elisabeth.degreef@uzbrussel.be

B. Hauser

e-mail: bruno.hauser@uzbrussel.be interval. This eRHF is an adequate and safe alternative to cow milk-based eHF.

Keywords Cow's milk protein allergy · Extensive hydrolysate $\cdot$ Extensively hydrolyzed rice protein formula

$\begin{array}{ll}\text { Abbreviations } \\ \text { AAP } & \text { American Academy of Pediatrics } \\ \text { CI } & \text { Confidence interval } \\ \text { CMP(A) } & \text { Cow's milk protein (allergy) } \\ \text { E(R)HF } & \begin{array}{l}\text { Extensive (rice) hydrolysate formulaESPGHAN } \\ \text { European Society of Paedaitric Gastroenterology, }\end{array} \\ & \begin{array}{l}\text { Hepatology and Nutrition } \\ \text { IgE }\end{array} \\ \text { Immunoglobulin E } \\ \text { PRHF } & \text { Partial rice hydrolysate formula } \\ \text { SBS } & \text { Symptom-based score } \\ \text { SPT } & \text { Skin-prick test } \\ \text { SIF } & \text { Soy infant formula } \\ \text { WHO } & \text { World Health Organization }\end{array}$

Introduction

Guidelines for the dietary management of infants diagnosed with cow's milk protein allergy (CMPA) recommend the substitution of cow's milk with extensively hydrolyzed casein or whey protein formulas (eHF) [3, $4,6,13]$. Up to $14 \%$ of infants with CMPA will also react to soy infant formula (SIF) [1, 4], even though tolerance of soy is better in immunoglobulin E (IgE) compared with non-IgE-mediated CMPA [27]. ESPGHAN and an Australian expert panel recommend not using SIF before the age of 6 months $[12,13]$. In addition, the American Academy of Pediatrics (AAP) recommends an eHF as a preferred therapeutic option 
with SIF as a second choice [4]. However, eHFs are substantially more expensive than standard or soy infant formulae and generally have a bitter taste, which often hampers their acceptability [4]. Moreover, some parents may look for vegetable alternatives due to various opinion or convictions. Some infants may still be intolerant or allergic to these eHFs $[3,6$, 13]. In those cases, amino acid formulae (AAF) are an effective dietary treatment $[4,6,13]$ but are even substantially more expensive and have also a bitter taste.

As a result, affordable and better-tasting dietary options in the treatment of CMPA would be welcomed as an alternative. Hydrolyzed formulas based on rice protein may offer such an option $[7,9,10,19,20]$. Therefore, the efficacy of such a new extensively hydrolyzed rice protein infant formula (eRHF) was evaluated in infants with CMPA.

\section{Materials and methods}

This study was conducted between April 2011 and March 2013. Infants who initially presented with symptoms suggesting CMPA were selected. Diagnostic criteria to suspect CMPA were based on the presence of a combination of the following symptoms: general discomfort (persistent distress or colic, $\geq 3 \mathrm{~h} /$ day and wailing/irritability at least 3 days/week since at least 1 week), gastrointestinal signs and symptoms (frequent regurgitation, vomiting, diarrhoea, constipation with or without perianal rash, and blood in the stools), respiratory symptoms (runny nose, otitis media, chronic cough, and wheezing unrelated to infection), and dermatological manifestations (atopic dermatitis, angio-oedema, urticaria unrelated to acute infections, drug intake, etc.) $[13,23,25]$. A symptom-based

Table 1 Symptom-based clinical score (adapted from refs. [20, 23, 24])

\begin{tabular}{|c|c|c|c|c|}
\hline \multirow{2}{*}{$\begin{array}{l}\text { Symptom } \\
\text { Crying }^{\mathrm{a}}\end{array}$} & \multicolumn{4}{|l|}{ Score } \\
\hline & \multirow[t]{7}{*}{0 to 6} & 0 & \multicolumn{2}{|l|}{$1 \mathrm{~h} /$ day } \\
\hline & & 1 & \multicolumn{2}{|l|}{$1-1.5 \mathrm{~h} /$ day } \\
\hline & & 2 & \multicolumn{2}{|l|}{$1.5-2 \mathrm{~h} /$ day } \\
\hline & & 3 & \multicolumn{2}{|l|}{2 to $3 \mathrm{~h} /$ day } \\
\hline & & 4 & \multicolumn{2}{|l|}{3 to $4 \mathrm{~h} /$ day } \\
\hline & & 5 & \multicolumn{2}{|l|}{4 to $5 \mathrm{~h} /$ day } \\
\hline & & 6 & \multicolumn{2}{|l|}{$>5 \mathrm{~h} /$ day } \\
\hline \multirow[t]{7}{*}{ Regurgitation [22] } & \multirow[t]{7}{*}{0 to 6} & 0 & \multicolumn{2}{|l|}{$0-2$ episodes/day } \\
\hline & & 1 & \multicolumn{2}{|l|}{$\geq 3$ to $\leq 5$ of small volume } \\
\hline & & 2 & \multicolumn{2}{|c|}{$>5$ episodes of $>1$ coffee spoon } \\
\hline & & 3 & \multicolumn{2}{|c|}{$>5$ episodes of \pm half of the feedings in $<$ half of the feedings } \\
\hline & & 4 & \multicolumn{2}{|c|}{ Continuous regurgitations of small volumes $>30 \mathrm{~min}$ after each feeding } \\
\hline & & 5 & \multicolumn{2}{|c|}{ Regurgitation of half to complete volume of a feeding in at least half of the feedings } \\
\hline & & 6 & \multicolumn{2}{|c|}{ Regurgitation of the complete volume after each feeding } \\
\hline \multirow{5}{*}{$\begin{array}{l}\text { Stools (according to } \\
\text { Bristol stool scale [15]) }\end{array}$} & \multirow[t]{5}{*}{0 to 6} & 4 & \multicolumn{2}{|l|}{ Types 1 and 2 (hard stools) } \\
\hline & & 0 & \multicolumn{2}{|c|}{ Types 3 and 4 (normal stools) } \\
\hline & & 2 & \multicolumn{2}{|c|}{ Type 5 (soft stool) } \\
\hline & & 4 & \multicolumn{2}{|c|}{ Type 6 (mushy/liquid stool, if unrelated to infection) } \\
\hline & & 6 & \multicolumn{2}{|l|}{ Type 7 (watery stools) } \\
\hline \multirow[t]{7}{*}{ Dermatological symptoms } & \multirow[t]{6}{*}{0 to 6} & \multicolumn{3}{|c|}{ Atopic eczema } \\
\hline & & & \multicolumn{2}{|r|}{ Arms-hands-legs-feet } \\
\hline & & Absent & 0 & 0 \\
\hline & & Mild & 1 & 1 \\
\hline & & Moderate & 2 & 2 \\
\hline & & Severe & 3 & 3 \\
\hline & 0 to 6 & \multicolumn{3}{|c|}{ Urticaria (0 no/6 yes) } \\
\hline Respiratory symptoms & 0 to 3 & 0 & No respiratory symptoms & \\
\hline & & 1 & Mild symptoms & \\
\hline & & 2 & Moderate symptoms & \\
\hline & & 3 & Severe symptoms & \\
\hline
\end{tabular}

${ }^{\text {a }}$ Crying was only considered if the child was crying for 1 week or more, assessed by the parents, without any other obvious cause 
score (SBS) considering the vast majority of the symptoms of CMPA reported in literature was developed and the severity of each presenting symptom was scored (Table 1) [21, 24, 25].

Infants were included after the diagnosis of CMPA was confirmed by a positive challenge, except if the challenge was contra-indicated, in accordance to recent guidelines [13]. The challenge was performed with standard infant formula, following a standardised challenge test procedure [13]. The challenge procedure lasted one week, of which the first half day consisted of gradual introduction of cow's milk protein (CMP). If no reaction occurred during this half day, parents administered at least $250 \mathrm{ml} /$ day of standard infant formula per day during 1 week. During that week, on a daily basis, parents had to fill in a diary with information on regurgitation, stools, and duration of crying. Parents had to report any change/reaction they noticed. If any, the child was presented at the outpatient clinic and the physician evaluated the evolution of the SBS. The paediatricians evaluated the SBS before and during the food challenge, as well as 1, 3, and 6 months after initiation of the dietary treatment with the eRHF. Baseline score was defined as the score reached when a positive reaction occurred during the challenge, both for immediate and late reactions. It was up to the physician to decide to perform a skin-prick test (SPT) and measure-specific IgE. The SPT was evaluated according to the standard criteria, i.e., a papula of $3 \mathrm{~mm}$ induration compared with a negative control with saline solution [8].

A positive challenge was the inclusion criterion for this study; included infants were fed with the new eRHF during 6 months. Infant formulas are the only recommended food for

Table 2 Average nutritional composition of the study formula

\begin{tabular}{llcc}
\hline & Unit & $/ 100 \mathrm{~g}$ & $/ 100 \mathrm{ml}$ \\
\hline Proteins & $\mathrm{g}$ & 13.4 & 1.8 \\
Fats & $\mathrm{g}$ & 25.5 & 3.4 \\
Saturated fatty acids & $\mathrm{g}$ & 9.9 & 1.3 \\
Monounsaturated fatty acids & $\mathrm{g}$ & 9.2 & 1.2 \\
Polyunsaturated fatty acids & $\mathrm{g}$ & 5.1 & 0.7 \\
Linoleic acid & $\mathrm{g}$ & 4.5 & 0.6 \\
Alpha-linolenic acid & $\mathrm{mg}$ & 425 & 57.4 \\
Medium-chain triglycerides & $\mathrm{g}$ & 2.3 & 0.3 \\
Carbohydrates & $\mathrm{g}$ & 49 & 6.6 \\
Maltodextrins & $\mathrm{g}$ & 46 & 6.2 \\
Starch & $\mathrm{g}$ & 1 & 0.1 \\
Fibers & $\mathrm{g}$ & 4 & 0.5 \\
Fibers & $\mathrm{g}$ & 4 & 0.5 \\
Energy & $\mathrm{kcal}$ & 487 & 65.7 \\
\hline
\end{tabular}

The composition of the formula may be adjusted for compliance to various regulations, without any impact on the hypoallergenicity of the formula, and its nutritional value

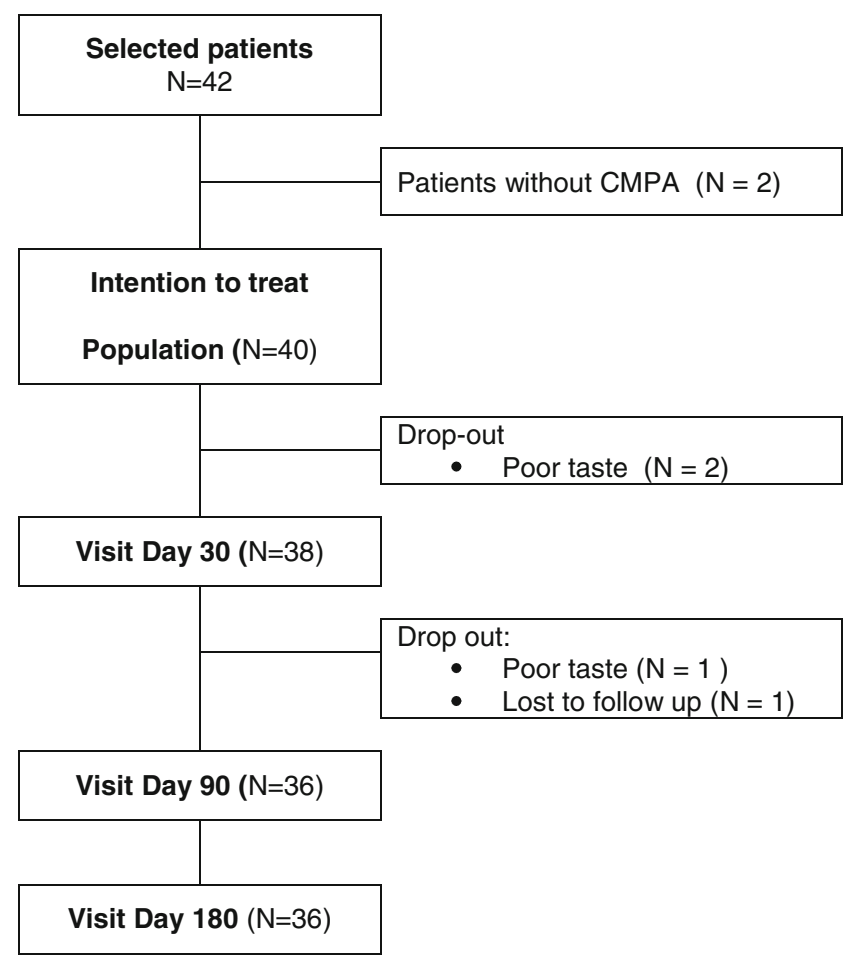

Fig. 1 Flow chart

infants below 6 months. Weaning foods were introduced following paediatricians' advice, with specific recommendation to avoid cow's milk containing products.

The SBS was evaluated 1, 3, and 6 months after initiation of the dietary treatment with the eRHF. Growth (weight and length) was monitored and evaluated as $z$-scores according to the WHO Child Growth Standards [26]. Feeding tolerance and adverse events were registered throughout the 6 months study period.

The test formula (NovaRice, United Pharmaceuticals) contains extensively hydrolyzed-rice protein supplemented with lysine and tryptophan to improve the nutritional quality by providing an amino-acid profile similar to that of mother's

Table 3 Description of the included population

\begin{tabular}{ll}
\hline Boy/girl & $21 / 19$ \\
Age at inclusion (months) mean+SD & $3.4+ \pm 1.5$ \\
Median (range) & $3(0-6)$ \\
Time since the first apparition of the symptoms (months), & $1.9 \pm 1.2$ \\
$\quad$ mean \pm SD & $1.8(0.2-5.4)$ \\
Median (range) & $9(23.1)$ \\
Infants never breast fed $(n(\%))$ & $5.2 \pm 5.0$ \\
Duration of exclusive breast feeding (weeks), mean $\pm \mathrm{SD}$ & $4(0-18)$ \\
Median (range) & $2.3 \pm 4.0$ \\
Duration of partial breast feeding (weeks; mean $\pm \mathrm{SD})$ & $1(0-16)$ \\
Median (range) & $36(90.0)$ \\
Infants with at least one parent or sibling having a proven & \\
$\quad$ or suspected allergic disease $(n(\%))$ & \\
\hline
\end{tabular}


Table 4 Evolution of the global symptom-based score (SBS)

Before Inclusion 1 month 3 months 6 months challenge $\quad(n=38) \quad(n=38) \quad(n=36) \quad(n=36)$

$\begin{array}{lllll}(n=38) & \text { (B) } & \text { (C) } & \text { (D) } & \text { (E) }\end{array}$

(A)

\begin{tabular}{|c|c|c|c|c|c|}
\hline $\begin{array}{c}\text { Mean } \pm \\
\text { SD }\end{array}$ & $8.6 \pm 5.6$ & $13.5 \pm 5.2$ & $3.5 \pm 2.3$ & $2.4 \pm 1.9$ & $1.5 \pm 2.0$ \\
\hline$p$ & & $\begin{array}{l}\mathrm{A}-\mathrm{B}, \\
\quad<0.0001^{\mathrm{b}}\end{array}$ & $\begin{array}{l}\mathrm{B}-\mathrm{C}, \\
\quad<0.001^{\mathrm{b}}\end{array}$ & $\begin{array}{l}\text { B-D, } \\
\quad<0.001^{\mathrm{a}}\end{array}$ & $\begin{array}{l}\text { B-E, } \\
\quad<0.001^{\mathrm{a}}\end{array}$ \\
\hline
\end{tabular}

${ }^{\text {a }}$ Paired Student's $t$ test

Table 5 Evolution of the different components of the symptombased score (SBS)
NS not significant

${ }^{a}$ Symmetry test

${ }^{\mathrm{b}}$ Paired Student's $t$ test

${ }^{\mathrm{c}}$ McNemar's test

${ }^{\mathrm{d}}$ Wilcoxon's test milk, in compliance with the recommendation of the EU Directive on infant formulas (composition of the formula, Table 2). More than $95 \%$ of the peptides in the eRHF have a molecular weight of less than $3 \mathrm{kDa}$, and most of these are under $1.5 \mathrm{kDa}$. It also contains a thickening complex using pectin, as extensive hydrolysates are particularly liquid. The formula is lactose free and complies with EU regulation.

The study was approved by the Ethical Committee of the UZ Brussel, acting as the leading center, and of each participating center; 14 investigators from 11 centers participated in

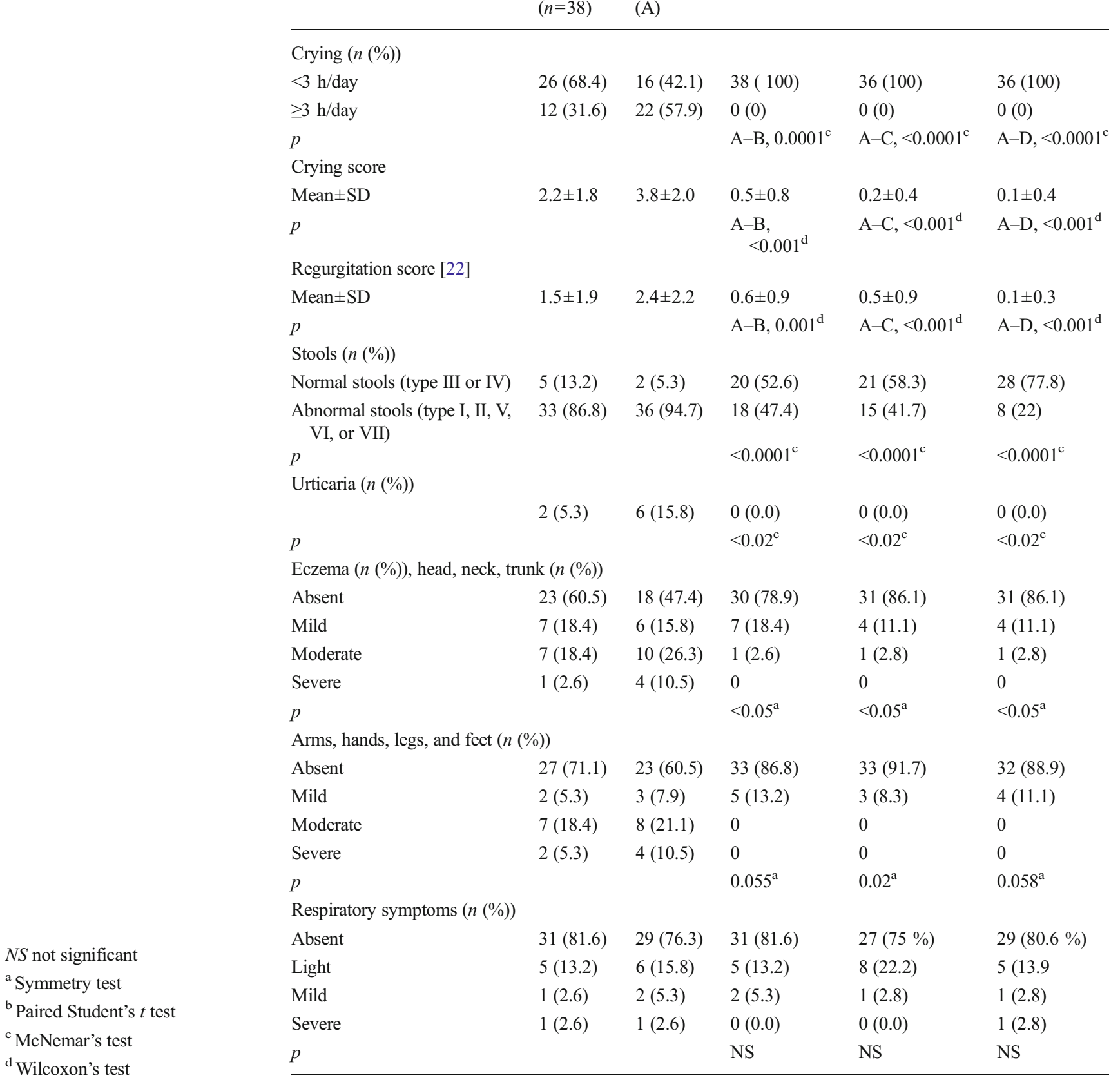


the trial. A written informed consent was obtained from all parents. United Pharmaceuticals provided free formula for the study period. The study was registered at clinicaltrials.gov NCT number NCT01998074

To be considered hypoallergenic, a therapeutic formula must demonstrate in a clinical study that with $95 \%$ confidence it does not provoke allergic reactions in $90 \%$ of infants or children with confirmed cow's milk allergy [3]. In case of no reaction, the lower $95 \%$ confidence interval (CI) for the proportion of patients with no reaction should be greater than $90 \%$; a sample size of 29 participants is sufficient to show hypo-allergenicity. Considering possible dropouts or deviation to inclusion criteria, the target was to recruit 36 patients. Statistical analysis was carried out using SAS 9.2 software. For qualitative parameters classified in two categories, McNemar's test was used and in case of more than 2 categories, symmetry test was used. Paired Student's $t$ test was used for quantitative parameters. The normality of distribution was systematically checked using Shapiro-Wilk's test and the Wilcoxon's test was used in case of non-normality.

\section{Results}

Forty-two patients were selected for the study. Forty infants were included (21 boys, 19 girls; age, 3.4+ 1.5 months (mean+SD); range, 0-6 months) (Fig. 1; Table 3). Thirty-eight infants had a positive challenge confirming CMPA and two patients were not challenged because of an initial anaphylactic reaction. This was the intention to treat population, used to assess the hypoallergenicity and growth parameters evolution. Fourteen out of 38 infants had an immediate type of reaction. A SPT was performed in 17 infants and was positive in 15 (mean wheal, $11 \mathrm{~mm}$ (range, 3-25 mm)).

Four patients dropped out before the end of the study (Fig. 1). Three parents decided to stop the trial because according to their opinion the infant did not like or accept the study formula and preferred the "initial" formula (which was given before the challenge). One patient did not show up for the visit after 1 month.

The tolerance was evaluated on the intention-to-treat population of 40 patients, consisting of all patients with a confirmed CMPA. None of them dropped out for intolerance.

Seventy-nine adverse events have been reported during the 6 months observation period. Among them, five were serious adverse events all unrelated to the study formula (two bronchiolitis, one pneumonia, and two pyelonephritis). One nonserious adverse event was reported as related to the study product, it was food refusal leading to the end of the study for this patient. Other adverse events were mainly related mainly to ear-nose-throat (73\%), gastro-intestinal tract infections $(14.9 \%)$, or varicella $(4.1 \%)$, the remaining (8\%) being various such as fever, conjunctivitis.

The SBS change was evaluated on the 38 allergic infants who were presented after one month eRHF feeding. Thirty-six out of 38 were fed the study formula for 6 months.

The SBS was significantly lower at each time point $(1,3$, or 6 months) than at baseline (Table 4, $p<0.001$ ).

All parameters composing the SBS score had decreased after 1 month of dietary treatment with the study formula (Table 5), and this evolution was confirmed after 3 and 6 months. At baseline, $5.3 \%$ of the infants had "normal" stools while after only one month feeding with the eHRF

Table 6 Anthropometric data at inclusion and after 1, 3, and 6 months feeding with the extensive rice hydrolysate

\begin{tabular}{|c|c|c|c|c|}
\hline & Inclusion & 1 month & 3 months & 6 months \\
\hline \multicolumn{5}{|l|}{ Age (months) } \\
\hline No. of subjects $(\mathrm{N})$ & 40 & 38 & 36 & 36 \\
\hline Mean \pm SD & $3.4 \pm 1.5$ & $4.4 \pm 1.5$ & $6.4 \pm 1.6$ & $9.6 \pm 1.7$ \\
\hline Range & $1-6$ & $2-7$ & $4-10$ & $7-13$ \\
\hline \multicolumn{5}{|l|}{ Weight $(\mathrm{kg})$} \\
\hline$N$ & 38 & 38 & 36 & 36 \\
\hline Mean \pm SD & $6.1 \pm 1.1$ & $6.7 \pm 1.1$ & $7.6 \pm 1.1$ & $8.8 \pm 1$ \\
\hline \multicolumn{5}{|l|}{ Weight-for-age $z$-score } \\
\hline Mean \pm SD & $-0.7 \pm 1.0$ & $-0.5 \pm 0.9$ & $-0.3 \pm 1.0$ & $-0.1 \pm 0.9$ \\
\hline$p$ (visit inclusion) & & $<0.001^{\mathrm{b}}$ & $<0.001^{\mathrm{a}}$ & $<0.001^{\mathrm{a}}$ \\
\hline \multicolumn{5}{|l|}{ Length $(\mathrm{cm})$} \\
\hline$N$ & 37 & 38 & 36 & 36 \\
\hline Mean \pm SD & $61.9 \pm 3.9$ & $64.3 \pm 3.7$ & $67.8 \pm 3.5$ & $72.1 \pm 3.3$ \\
\hline \multicolumn{5}{|l|}{ Length-for age $z$-score } \\
\hline Mean \pm SD & $-0.1 \pm 1.0$ & $-0.1 \pm 1.1$ & $-0.1 \pm 1.1$ & $-0.1 \pm 1.1$ \\
\hline$p$ (visit inclusion) & & $\mathrm{NS}^{\mathrm{a}}$ & $\mathrm{NS}^{\mathrm{a}}$ & $N S^{\mathrm{a}}$ \\
\hline \multicolumn{5}{|c|}{ Weight-for-length $z$-score } \\
\hline Mean \pm SD & $-0.7 \pm 0.9$ & $-0.5 \pm 0.8$ & $-0.3 \pm 0.9$ & $0 \pm 0.8$ \\
\hline$p$ (visit inclusion) & & $0.018^{\mathrm{a}}$ & $<0.001^{\mathrm{a}}$ & $<0.001^{\mathrm{a}}$ \\
\hline \multicolumn{5}{|l|}{ BMI $\left(\mathrm{kg} / \mathrm{m}^{2}\right)$} \\
\hline$N$ & 37 & 38 & 36 & 36 \\
\hline Mean \pm SD & $15.7 \pm 1.6$ & $16.2 \pm 1.4$ & $16.5 \pm 1.3$ & $16.8 \pm 1.2$ \\
\hline \multicolumn{5}{|l|}{ BMI-for-age $z$-score } \\
\hline Mean \pm SD & $-0.7 \pm 0.9$ & $-0.6 \pm 0.8$ & $-0.4 \pm 0.9$ & $0.0 \pm 0.8$ \\
\hline$p$ (visit inclusion) & & $0.012^{\mathrm{a}}$ & $<0.001^{\mathrm{a}}$ & $<0.001^{\mathrm{a}}$ \\
\hline \multicolumn{5}{|c|}{ Head circumference $(\mathrm{cm})$} \\
\hline$N$ & 37 & 38 & 36 & 36 \\
\hline Mean \pm SD & $40.8 \pm 1.9$ & $42.1 \pm 1.6$ & $43.6 \pm 1.8$ & $45.5 \pm 1.6$ \\
\hline \multicolumn{5}{|c|}{ Head circumference $z$-score } \\
\hline Mean \pm SD & $0.1 \pm 1.1$ & $0.3 \pm 0.9$ & $0.3 \pm 1.2$ & $0.5 \pm 1.0$ \\
\hline$p$ (visit inclusion) & & $0.020^{\mathrm{b}}$ & $\mathrm{NS}^{\mathrm{a}}$ & $<0.001^{\mathrm{a}}$ \\
\hline
\end{tabular}

$p$ values are related to $z$-score variation between inclusion and each visit

${ }^{\text {a }}$ Student's $t$ test

${ }^{\mathrm{b}}$ Wilcoxon's test 
$52.6 \%$ had normal stools $(p<0.0001)$. At the end of the 6month period, $77.8 \%$ of the infants had normal stools. At baseline, $57.9 \%$ of the infants were crying more than $3 \mathrm{~h} /$ day, whereas, after 1 month, none of the infants were crying more than $3 \mathrm{~h} /$ day $(p<0.0001)$, and $65.8 \%$ were crying less than $1 \mathrm{~h}$ /day. At three months, $86.1 \%$ of the infants were crying less than 1 hour a day. The regurgitation score [24] decreased by $75 \%$ over 1 month (from $2.4+2.2$ to $0.6 \pm 0.9, p<0.0001)$, and this decrease persisted at days $90 \overline{(0.5+0.9)}$ and $180(0.1+0.3)$.

Thirty-six infants were fed with the study formula for at least 6 months. Growth parameters were evaluated as $z$-scores according to the WHO Child Growth Standards [21] and are shown in Table 6 and Fig. 2. At inclusion, weight-for-

Evolution of Weight-for-age (Boys)

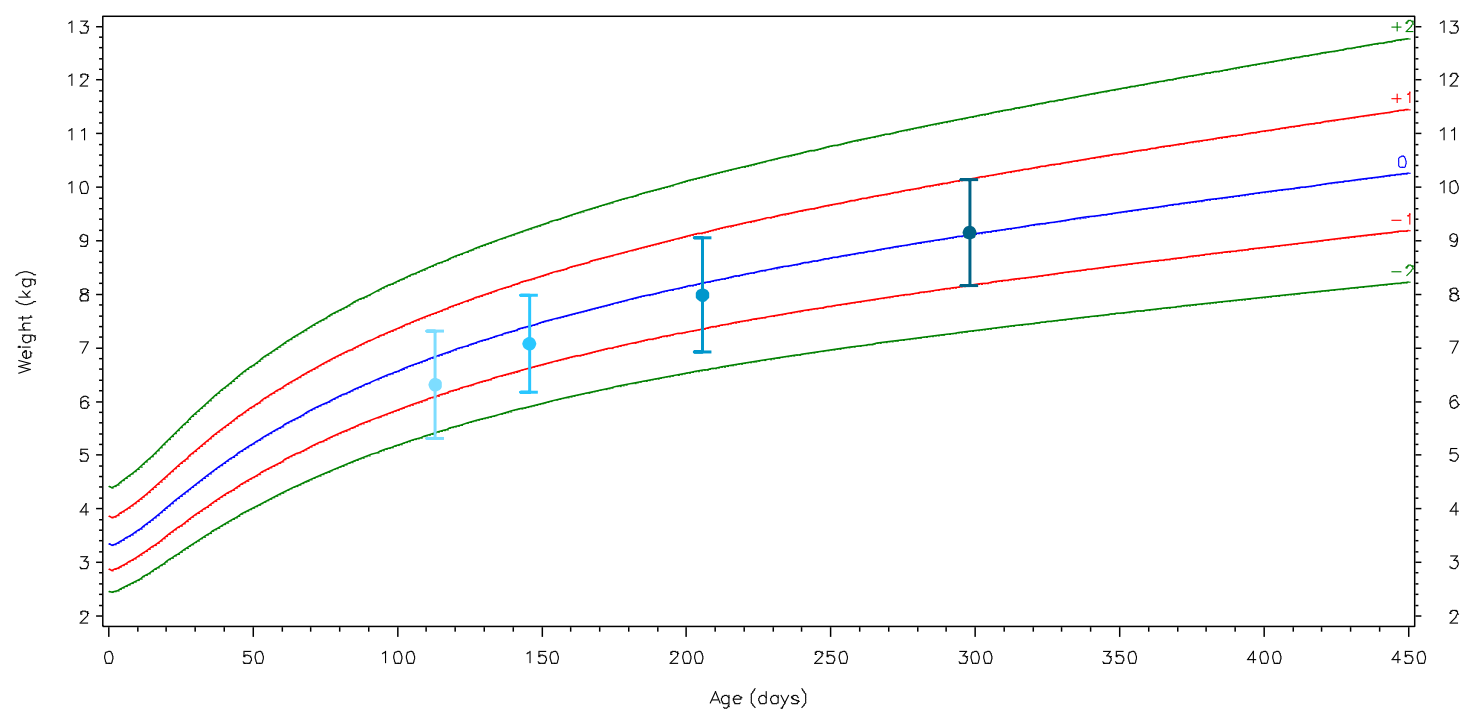

Visit $\bullet$ Inclusion Day $30 \bullet-$ Day $90 \bullet \bullet$ Day 180

Evolution of Weight-for-age (Girls)

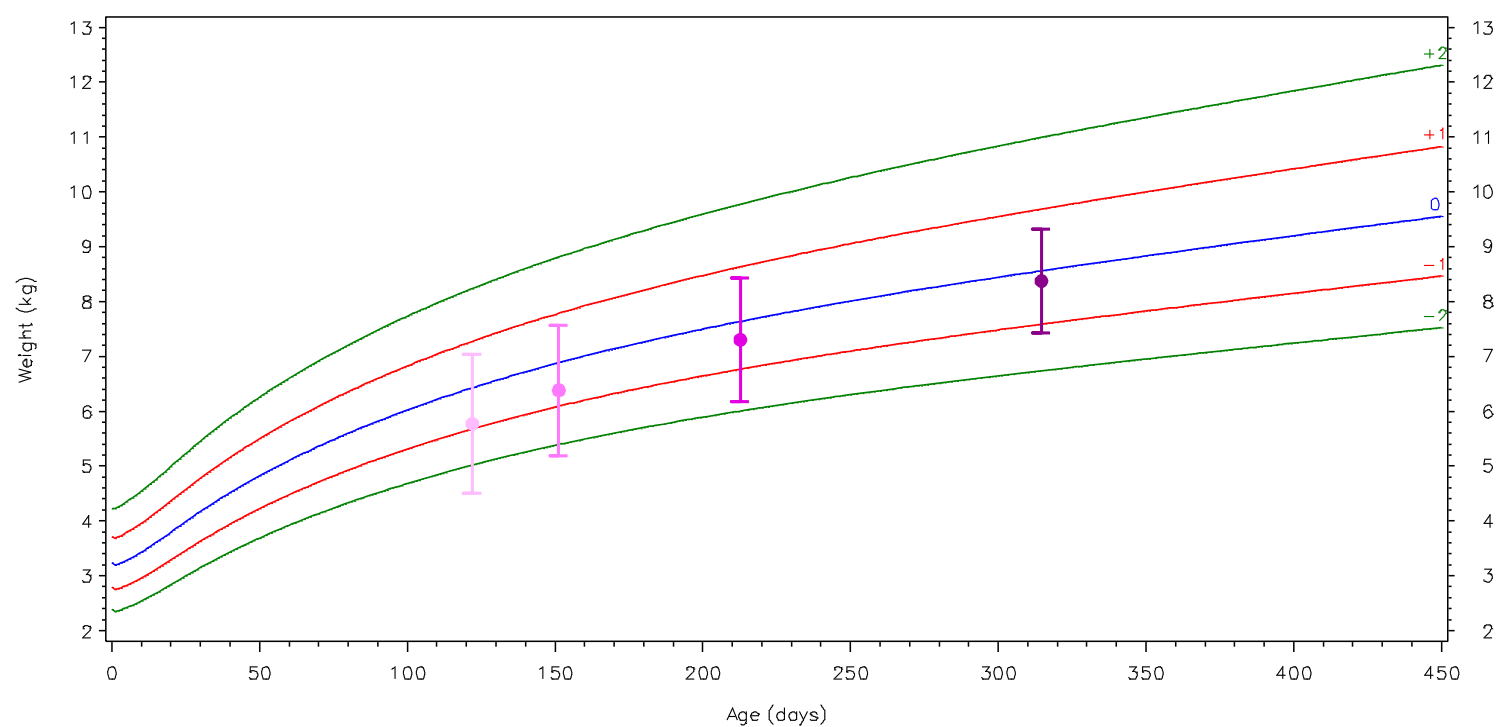

Visit Inclusion $\bullet$ Doy $30 \bullet \bullet$ Doy $90 \bullet \bullet$ Doy 180

Fig. 2 Evolution of weight-for-age $z$-score for boys and girls 
age, weight-for-length, and BMI $z$-scores were all negative $(-0.7)$ indicating a slight growth faltering. As of the 1 st month of feeding with the study formula, the weight-for-age, weightfor-length, and BMI $z$-scores significantly increased and were normalized with a catching up of the WHO Child Growth Standards by the end of the study period.

\section{Discussion}

This extensively hydrolyzed rice protein formula was tolerated by infants with a proven CMPA and contributed to catchup growth. To date, all studies with hydrolyzed rice protein formulas (RHF) were performed with a partial rice protein hydrolysate (pRHF). Nevertheless, these studies also focused on their tolerance in infants with CMPA [9, 10, 19]. Two studies by Fiocchi et al have shown that infants with CMPA and other food allergies tolerated pRHF $[9,10]$. Reche et al. demonstrated a $95 \%$ efficacy rate with a pRHF in infants with CMPA [19]. We demonstrated a $100 \%$ efficacy rate with this eRHF.

Despite the doubts raised in an article [20] regarding the nutritional adequacy of pRHF, growth was shown to be adequate in this trial as well as in other studies carried out using a pRHF in infants with CMPA $[2,14]$. A normalization of the weight-for-age, weight-for-length, and BMI was observed in those infants presenting on average a faltering growth at inclusion (mean weight-for-age, weight-for-length, and BMI $z$-scores of -0.7 ).

Rice has also recently been criticized regarding its possible arsenic content. However, this concerned mainly organic brown rice syrup and was not related to infant formula based on extensively hydrolyzed rice protein. There is no EU regulation fixing limits to arsenic in infant formulas. In particular, this study formula contains less than $10 \mu \mathrm{g} / \mathrm{L}$ of arsenic, which is the maximum content allowed in drinking water according to EU regulation [5] (drinking water being the only food in which arsenic content is regulated) and infant formulas are reconstituted with approximately 86 to $87 \%$ of water. In this study, the rice-protein based formula was generally well tolerated, with parents of three patients ending the study formula with the argument that their infant did not like the taste of the formula. In general, one of the main complaints of parents is that infants refuse hydrolyzed formulas because of their unpleasant bitter taste. A double-blind study evaluating the palatability of different formulas used to feed infants with CMPA showed that soy and rice-based formulas had better taste scores than CMP hydrolyzed formulas [18]. Good acceptability because of its pleasant odor, taste, and flavor was confirmed for rice formulas in healthy infants $[9,19]$. In this study, while acceptance was not unanimous, $81.2 \%$ of the parents reported that infants liked the taste of the formula.

Moreover, in this study, a normalization of the stool's consistency was observed as of the first month of feeding with the thickened eRHF whereas frequent and/or liquid stools are often associated with feeding children with hydrolyzed protein formula [17] (before the challenge, only $13.2 \%$ of the infants had normal stools; Table 7).

Hydrolyzed formulas are very liquid. Although they have been reported in literature to not increase regurgitation [11], there are conflicting data suggest they increase the frequency of regurgitation by $18 \%$ [16]. In this study, regurgitation decreased significantly during the first month of feeding with the thickened eRHF. The same thickening complex was added to en extensive hydrolysed CMP (casein) based formula and had similar beneficial effects on normalization of stool consistency as well as a decrease of regurgitation in infants with CMPA [21]. Besides efficacy, nutritional value and acceptability, the cost of infant formula is also of importance as affordability may promote compliance. While cost of infant formulas differ from country to another, overall it can be said that the cost of eRHF is significantly less than one of an extensive cow milk hydrolysate.

In conclusion, the study formula was tolerated by more than $90 \%$ of infants with a demonstrated CMPA, with a $95 \%$ CI. The formula also ensured a proper growth of those infants. The excellent acceptability of the eRHF tested makes this kind of formula an interesting option in the treatment of CMPA in terms of efficacy, nutritional value, affordability, acceptance, and tolerance. However, more studies with a greater number of subjects targeting safety, anthropometric growth and development with these new formulas are needed.

Table 7 Evolution of stool consistency according to the Bristol stool scale

\begin{tabular}{|c|c|c|c|c|c|}
\hline & Before challenge & At inclusion & 1 month & 3 months & 6 months \\
\hline $\begin{array}{l}\text { Type } 1 \text { or } 2 \text { : separate hard lumps, like nuts (hard to pass), } \\
\text { or sausage-shaped, but lumpy }\end{array}$ & $11(28.9 \%)$ & $9(23.7 \%)$ & $3(7.9 \%)$ & $2(5.6 \%)$ & $0(0 \%)$ \\
\hline Type 3 or 4 : like a sausage or snake smooth and soft & $5(13.2 \%)$ & $2(5.3 \%)$ & $20(52.6 \%)$ & $21(58.3 \%)$ & $28(77.8 \%)$ \\
\hline Type 5: soft blobs with clear cut edges (passes easily) & $9(23.7 \%)$ & $4(10.5 \%)$ & $4(10.5 \%)$ & $8(22.2 \%)$ & $5(13.9 \%)$ \\
\hline Type 6: fluffy pieces with ragged edges, a mushy stool & $9(23.7 \%)$ & $11(28.9 \%)$ & $10(26.3 \%)$ & $5(13.9 \%)$ & $2(5.6 \%)$ \\
\hline Type 7: watery, no solid pieces, or entirely liquid & $4(10.5 \%)$ & $12(31.6 \%)$ & $1(2.6 \%)$ & $0(0 \%)$ & $1(2.8 \%)$ \\
\hline
\end{tabular}


Funding United Pharmaceuticals provided free formula and financial support for the research.

Conflict of interest Y. Vandenplas is a consultant for United Pharmaceuticals and Biocodex. The other authors did not report a COI.

Open Access This article is distributed under the terms of the Creative Commons Attribution License which permits any use, distribution, and reproduction in any medium, provided the original author(s) and the source are credited.

\section{References}

1. Agostoni C, Axelsson I, Goulet O, ESPGHAN committee of Nutrition (2006) Soy protein infant formulae and follow on formulae a commentary by the ESPGHAN. J Pediatr Gastroenterol Nutr 42(4):352-361

2. Agostoni C, Fiocchi A, Riva E, Terracciano L, Sarratud T, Martelli A, Lodi F, D'Auria E, Zuccotti G, Giovannini M (2007) Growth of infants with IgE-mediated cow's milk allergy fed different formulas in the complementary feeding period. Pediatr Allergy Immunol 18(7):599-606

3. American Academy of Pediatrics (2000) Committee on Nutrition. Hypoallergenic infant formula. Pediatrics 106(2Pt1):346-349

4. Bhatia J, Greer F, American Academy of Pediatrics Committee on Nutrition (2008) Use of soy protein-based formulas in infant feeding. Pediatrics 121(5):1062-1068. doi: 10.1542/peds.2008-0564

5. Commission Directive $98 / 83 / \mathrm{EC}$ on the quality of water intended for human consumption

6. Committee on Nutrition of the French Pediatrics Society (2000) Use of infant formulas with reduced antigenic content. Arch Pediatr 7(3): 302-306

7. D’Auria E, Sala M, Lodi F, Radaelli G, Riva E, Giovannini M (2003) Nutritional value of a rice-hydrolysate formula in infants with cows' milk protein allergy: a randomized pilot study. J Int Med Res 31(3): 215-222

8. Dreborg S, Frew A (1993) EAACI Position paper: allergen standardization and skin tests. Allergy 48(suppl 14):48-82

9. Fiocchi A, Restani P, Bernardini R, Lucarelli S, Lombardi G, Magazzù G, Marseglia GL, Pittschieler K, Tripodi S, Troncone R, Ranzini C (2006) A hydrolyzed rice-based formula is tolerated by children with cow's milk allergy: a multi-centre study. Clin Exp Allergy 36(3):311-316

10. Fiocchi A, Travaini M, D'Auria E, Banderali G, Bernardo L, Riva E (2003) Tolerance to a rice hydrolysate formula in children allergic to cow's milk and soy. Clin Exp Allergy 33(11):1576-1580

11. Hauser B, Keymolen K, Blecker U, Suys B, Vandenplas Y (1993) A comparative evaluation of whey hydrolysate and whey-predominant formulas. How well do infants accept and tolerate them? Clin Pediatr (Phila) 32(7):433-437

12. Kemp AS, Hill DJ, Allen KJ, Anderson K, Davidson GP, Day AS, Heine RG, Peake JE, Prescott SL, Shugg AW, Sinn JK, Australian consensus panel (2008) Guidelines for the use of infant formulas to treat. CMP allergy: an Australian consensus panel opinion. Med J Austr 188(2):109-112

13. Koletzko S, Niggemann B, Arato A, Dias JA, Heuschkel R, Husby S, Mearin ML, Papadopoulou A, Ruemmele FM, Staiano A, Schäppi MG, Vandenplas Y, European Society of Pediatric Gastroenterology, Hepatology, and Nutrition (2012) Diagnostic approach and manage- ment of cow's-milk protein allergy in infants and children: ESPGHAN GI Committee practical guidelines. J Pediatr Gastroenterol Nutr 55(2):221-229. doi: 10.1097/MPG. 0b013e31825c9482

14. Lasekan JB, Koo WK, Walters J, Neylan M, Luebbers S (2006) Growth, tolerance and biochemical measures in healthy infants fed a partially hydrolyzed rice protein-based formula: a randomised, blinded prospective trial. J Am Coll Nutr 25(1): $12-19$

15. Lewis SJ, Heaton KW (1997) Stool form scale as a useful guide to intestinal transit time. Scand J Gastroenterol 32(9):920-924

16. Medjad-guillou N, Henocq A, Arnaud-Battandier F (1992) Does the hydrolysis of proteins change the acceptability and the digestive tolerance of milk for infants? The results of a comparative and randomized prospective study. Ann Pediatr 39(3):202-206

17. Niggemann B, von Berg A, Bollrath C, Berdel D, Schauer U, Rieger C, Haschke-Becher E, Wahn U (2008) Safety and efficacy of a new extensively hydrolyzed formula for infants with cow's milk protein allergy. Pediatr Allergy Immunol 19(4):348-354. doi: 10.1111/j. 1399-3038.2007.00653

18. Pedrosa M, Pascual CY, Larco JI, Esteban MM (2006) Palatability of hydrolysates and other substitution formulas for cow's milk-allergic children: a comparative study of taste, smell, and texture evaluated by healthy volunteers. J Investig Allergol Clin Immunol 16(6):351-356

19. Reche M, Pascual C, Fiandor A, Polanco I, Rivero-Urgell M, Chifre R, Johnston S, Martín-Esteban M (2010) The effect of a partially hydrolyzed formula based on rice protein in the treatment of infants with cow's milk protein allergy. Pediatr Allergy Immunol 21(4Pt1): 577-585. doi: 10.1111/j.1399-3038.2010.00991

20. Savino F, Castagno E, Monti G, Serraino P, Peltran A, Oggero R, Fanaro S, Vigi V, Silvestro L (2005) Z-score of weight for age of infants with atopic dermatitis and cow's milk allergy fed with a ricehydrolysate formula during the first two years of life. Acta Paediatr Suppl 94(449):115-119

21. Vandenplas Y, De Greef E, ALLAR study group (2014) Extensive protein hydrolysate formula effectively reduces regurgitation in infants with positive and negative challenge tests for cow's milk allergy. Acta Paediatr (in press)

22. Vandenplas Y, Hachimi-Idrissi S, Casteels A, Mahler T, Loeb H (1994) A clinical trial with an anti-regurgitation formula. Eur J Pediatr 153(6):419-423

23. Vandenplas Y, Koletzko S, Isolauri E, Hill D, Oranje AP, Brueton M, Staiano A, Dupont C (2007) Guidelines for the diagnosis and management of cow's milk protein allergy in infants. Arch Dis Child 92(10):902-908

24. Vandenplas Y, Steenhout P, Grathwohl D, Althera Study Group (2014) A pilot study on the application of a symptom-based score for the diagnosis of cow's milk protein allergy. SAGE Open Med 2: 2050312114523423

25. Vandenplas Y, Steenhout P, Planoudis Y, Grathwohl D, Althera Study Group (2013) A double-blind randomized trial comparing two extensively hydrolyzed formulaswith probiotics for the treatment of cow's milk protein allergy. Acta Paediatr 102(10):990-998. doi: 10. 1111/apa.12349

26. WHO Child Growth Standards The WHO Multicentre Growth Reference Study (MGRS)

27. Zeiger RS, Sampson HA, Bock SA, Burks AW Jr, Harden K, Noone S, Martin D, Leung S, Wilson G (1999) Soy allergy in infants and children with IgE-associated cow's milk allergy. J Pediatr 134(5): 614-622 